ISSN: 2302-8556

E-Jurnal Akuntansi Universitas Udayana

Vol.25.3.Desember (2018): 1634 - 1661

DOI: https://doi.org/10.24843/EJA.2018.v25.i03.p01

\title{
Pengaruh Kualitas Sistem Informasi Akuntansi pada Profitabilitas dengan Ketidakpastian Tugas sebagai Variabel Pemoderasi
}

\author{
Gede Hara Yogiswara ${ }^{1}$ \\ I Made Sadha Suardikha
}

${ }^{1}$ Fakultas Ekonomi dan Bisnis Universitas Udayana (Unud), Bali, Indonesia email: harayogi01@gmail.com/ Telp: +62 8971923579

${ }^{2}$ Fakultas Ekonomi dan Bisnis Universitas Udayana (Unud), Bali, Indonesia

\begin{abstract}
ABSTRAK
Tujuan penelitian ini adalah untuk memberi bukti empiris pengaruh kualitas sistem informasi akuntansi (SIA)dan untuk memberi bukti empiris pengaruh ketidakpastian tugas dalam memoderasi pengaruh kualitas SIA pada profitabilitas.Penelitian ini menggunakan variabel dependen yaitu profitabilitas yangdiukur menggunakan proksi ROA. Variabel independen yang digunakan, yaitu kualitas SIA yang diukur menggunakan 10 pernyataan dengan skala Likert 5 poin, dan variabel moderasi menggunakan ketidakpastian tugasyangdiukur dengan menggunakan 4pernyataan skala Likert 5 poin. Populasi pada penelitian ini adalah seluruh LPD yang terdapat di Kota Denpasar. teknik sampel jenuhmerupakan teknik sampel yang digunakan, sehingga dalam penelitian ini sampel berjumlah 35 LPD. Teknik analisis yang digunakan yaitu teknik analisis regresi linier sederhana dan MRA.

Kata kunci : profitabilitas kualitas sistem informasi akuntansi, , ketidakpastian tugas.
\end{abstract}

\begin{abstract}
The purpose of this study was to provide empirical evidence of the effect of the quality of accounting information systems (SIA) and to provide empirical evidence of the effect of task uncertainty in moderating the effect of SIA quality on profitability. This study uses the dependent variable that is profitability measured using ROA proxy. The independent variables used, namely the quality of the SIA measured using 10 statements with a 5-point Likert scale, and the moderating variable using task uncertainty measured using 4 5-point Likert scale statements. The population in this study is all LPDs located in Denpasar City. The sample determination technique used is saturated sample technique so that the sample in this study amounted to 35 LPDs. The analysis technique used is simple linear regression analysis technique and MRA.
\end{abstract}

Keywords : quality information system accounting, profitability, task uncertainty. 


\section{PENDAHULUAN}

Kualitas Sistem Informasi Akuntansi merupakan suatu subsistem atau komponen dari suatu organisasi, yang memiliki tanggung jawab dalam mempersiapkan informasi keuangan untuk membantu manajemen dalam proses pembuatan keputusan (Solikin, 2010). Sebagai sebuah subsistem organisasi, sistem informasi akuntansi melalui beberapa proses aktivitas manajemen, yaitu berupa mengumpulkan, mengklasifikasi, mengolah, menganalisis, dan mengkomunikasikan informasi finansial dan pengambilan keputusan yang relevan bagi pihak internal maupun eksternal perusahaan.

Baik buruknya kualitas output sistem informasi akuntansi dipengaruhi oleh tiga faktor, yaitu: isi informasi, waktu penyajian, dan bentuk penyajian. Ketiga penentu tersebut dapat dikendalikan oleh manajemen sehingga manajemen harus menjaga agar penentu (variabel) tersebut dapat meningkatkan kualitas informasi (Kadir, 2003). Agar kualitas informasi akuntansi yang disajikan dalam bentuk laporan dapat digunakan sebagai dasar pembuatan keputusan, maka akuntansi dituntut untuk dapat menyajikan informasi akuntansi yang relevan, akurat, dantepat waktu (Solikin, 2010).

Menurut Norita (2003) agar bagian akuntasi dapat menyajikan informasi akuntansi yang memenuhi karakteristik relevan, akurat, dan tepat waktu, maka dibutuhkan staf bagian akuntansi yang berkualitas, mempunyai tingkat pendidikan yang memadai dan pengalaman kerja yang cukup lama dalam mengelola bagian akuntansi. Oleh karena itu, diharapkan staf bagian akuntansi memiliki kemampuan 
ISSN: 2302-8556

E-Jurnal Akuntansi Universitas Udayana

Vol.25.3.Desember (2018): 1634 - 1661

menggunakan teknologi mengoperasikan berbagai program komputer dalam mengolah data untuk memperoleh informasi khususnya di bidang akuntansi yang akurat dan tepat pada waktunya, yang akan dipergunakan sebagai dasar dalam pembuatan keputusan. Pengolahan informasi berbasis komputer akan memudahkan dalam mengolah data menjadi informasi serta mengurangi kesalahan yang sering terjadi pada sistem manual.

Sebagai bagian dari sistem perbankan di Indonesia, LPD juga tidak lepas dari tuntutan untuk menyajikan informasi keuangan yang relevan, akurat, dan tepat waktu. Selain itu, tren perkembangan sistem informasi akuntansi berbasis komputer pada dunia perbankan ikut memicu LPD di Bali menerapkan sistem informasi akuntansi. Sebagai pembina teknis, Bank Pembangunan Daerah Bali (BPD Bali) berperan besar dalam mendorong LPD di Bali untuk mengganti pengelolaan akuntansi manual menjadi berbasis komputer. Dengan menerapkan sistem tersebut, diharapkan LPD mampu memberi pelayanan yang terbaik pada nasabah.

LPD di Bali merupakan entitas berbasis adat yang memiliki ciri khas khusus dibandingkan dengan LPD/lembaga keuangan mikro di daerah lain. LPD dimiliki oleh desa adat/desa pakraman yang diatur dalam Peraturan Gubernur Bali Nomor 44 Tahun 2017 tentang Lembaga Perkreditan Desa. LPD juga menerapkan unit operasional yang mengelola kekayaan milik desa pakraman. Selain ciri khas tersebut, jika dilihat dari bidang usaha yang dilakukan, LPD pada dasarnya adalah lembaga keuangan yang mempunyai aktifitas hampir sama dengan lembaga perbankan 
lainnya, yaitu menerima simpanan, memberikan pinjaman, dan deposito. Tujuan LPD adalah meningkatkan taraf hidup krama desa.

Keberadaan LPD yang sehat akan sangat membantu, baik secara ekonomi maupun sosial. Secara ekonomi, masyarakat memiliki alternatif untuk menyimpan dananya secara produktif dengan memperoleh pendapatan bunga. Untuk dapat memperolehdana dengan proses yang mudah, LPD merupakan pilihan utama bagi masyarakat. Tidak semua masyarakat di Bali berkesempatan memperoleh layanan dari perbankan besar, khususnya terkait dengan pinjaman untuk modal usaha. Diharapkan dengan adanya LPD akan membantu masyarakat desa untuk memperoleh modal usaha serta memenuhi kebutuhan hidup lainnya.

Perkembangan Lembaga Perkreditan Desa (LPD) di Bali cukup pesat. Buktinya, dari hanya sebanyak 8 LPD pada tahun 1984 lalu, pada tahun 2016 jumlahnya sudah mencapai 1.443 LPD. Ribuan LPD ini tersebar di 9 kabupaten/ kota di Bali. Namun tidak semua LPD berkembang dengan baik. Dari data yang didapatkan Pansus LPD, tercatat sebanyak 158 LPD (11,03 persen) di Bali yang justru dinyatakan bangkrut karena sudah tidak beroperasi lagi. Dari jumlah tersebut, LPD yang bangkrut paling banyak terdapat di Kabupaten Tabanan, yakni mencapai 54 LPD. Disusul di Kabupaten Gianyar 31 LPD, Buleleng 25 LPD, Karangasem 24 LPD, Badung dan Bangli masing-masing 8 LPD, Klungkung 4 LPD dan Jembrana 1 LPD. Salah satu kasus yang terjadi yaitu pada Lembaga Perkreditan Desa Banyupoh, Kabupaten Buleleng, terancam bangkrut akibat korupsi yang dilakukan oleh pengurus LPD tersebut. LPD Banyupoh sudah vakum akibat skandal korupsi pengurus, dalam 
ISSN: 2302-8556

E-Jurnal Akuntansi Universitas Udayana

Vol.25.3.Desember (2018): 1634 - 1661

kasus ini dana senilai Rp100 juta yang dikelola LPD Banyupoh sebesar Rp80 juta di antaranya dikorupsi oleh pengurus. Koordinator Tim Penanggulangan Masalah (TPM) LPD Banyupoh Gusti Mangku Kompyang mengungkapkan bahwa Ketua LPD Banyupoh Gede Sanjaya dan tiga pengurus lainnya menggunakan dana Rp80 juta untuk kepentingan pribadi.

Sebagian besar usaha kecil yang tidak menggunakan sistem informasi akuntansi menghasilkan keuntungan yang lebih kecil (Muhindo, 2014). Penerapan sistem informasi akuntansi memungkinkan suatu organisasi untuk memanajemen sumber daya yang berharga di perusahaan, yaitu informasi. Informasi tersebut merupakan hasil data yang didapatkan melalui transaksi-transaksi yang dicatat pada sistem. Dalam peningkatan profit (keuntungan) terkait kinerja Manajemen, LPD patut mempertimbangkan faktor-faktor yang dapat menghambat kinerja LPD. faktor ketidakpastian tugas yang tinggi merupakan salah satunya, faktor tersebut muncul dikarenakan kurangnya informasi untuk kejadian-kejadian masa mendatang yang tidak diprediksi oleh manajemen. faktor ketidakpastian tugas akan menghambat pencapaian keuntungan Jika sistem informasi akuntansi tidak mampu menyediakan informasi yang spesifik tentang keuangan LPD.

ketidakpastian tugas sebagai kekurangan informasi tentang kejadian-kejadian masa mendatang sehingga alternatif tindakan yang akan dihasilkan susah untuk diprediksi (Syam,2000). Hirts (1981) membagi ketidakpastian tugas menjadi tiga, yaitu: ketidakpastian tugas tinggi, ketidakpastian tugas sedang, dan ketidakpastian tugas rendah. Abdel et al. (2012) menyatakan bahwa dalam persaingan bisnis, setiap 
perusahaan menginginkan pencapaian pertumbuhan dan keberlangsungan usahanya melalui peningkatan keuntungan. Keuntungan tinggi merupakan dampak dari pengambilan keputusan strategis, efektif, dan efisien. Selain didasarkan pada informasi yang tepat dan akurat, pengambilan keputusan akan berdampak signifikan jika dilakukan secara fungsional serta adanya kepastian tugas bagi pengurus. Pengambilan keputusan yang tidak tepat akan berdampak kepada kinerja perusahaan yang menurun yang pada akhirnya berdampak kepada tingkat profitabilitas perusahaan.

Alasan ketidakpastian tugas sebagai variabel pemoderasi pada penelitian ini, dikarenan LPD dalam struktur manajemen atau struktur kepengurusannya masih terdapat pengurus LPD merangkap jabatan, rangkap jabatan berkaitan dengan masalah fungsi, tugas, dan kepentingan-kepentingan berdampak negatif pada kualitas keputusan yang akan diambil. Hal tersebut menyebabkan, pengambilan keputusan yang didasari dari hasil SIA tidak dapat dipergunakan secara efektif, sehingga berdampak pada kinerja.

LPD sebagai lembaga keuangan adat dalam peranannya memajukan maupun meningkatkan perekonomian masyarakat desa masih kurang optimal. Terbukti beberapa LPD mengalami masalah. Maju mundurnya LPD tergantung pada sumber daya manusia (SDM) pengelolanya. .Pengelola LPD yang merangkap jabatan akan menimbulkan ketidakpastian tugas. Tjahjono (2002) menyatakan ketidakpastian tugas merupakan hal penting dalam menjelaskan kinerja sistem informasi. Apabila derajat 
ISSN: 2302-8556

E-Jurnal Akuntansi Universitas Udayana

Vol.25.3.Desember (2018): 1634 - 1661

ketidakpastian tugas tinggi akan dapat membingungkan para karyawan dalam perusahaan, sehingga berpengaruh pada kinerja mereka.

Brownell (1982) mengelompokkan teori kontijensi kedalam empat bagian yaitu: individual, interpersonal, struktur organisasional, dan kultural. Ketidakpastian tugas merupakan salah satu dari variabel kontekstual, yaitu struktur organisasional. Riyanto (2001) menyatakan dalam teori kontijensi terdapat variabel yang berperan sebagai faktor pemoderasi yang dapat memengaruhi hubungan diantara kualitas SIA dengan profitabilitas.

Profitabilitas keuangan perusahaan dideskripsikan dalam bentuk laporan labarugi yang merupakan bagian dari laporan keuangan korporasi, yang dapat digunakan oleh semua pihak yang berkepentingan untuk membuat keputusan ekonomi. Berdasarkan laporan keuangan yang diterbitkan perusahaan, selanjutnya diperoleh informasi mengenai posisi keuangan perusahaan, struktur permodalan, aliran kas, kinerja keuangan, dan informasi lain yang mempunyai relevansi dengan laporan keuangan perusahaan. Profitabilitas juga digunakan untuk mengetahui efektifitas perusahaan dalam kegiatan memanajemen sumber daya yang dimiliki (Shapiro, 1991).

Tingkat profitabilitas suatu perusahaan dapat dilihat dari net profit (laba/rugi bersih sesudah pajak) (Srimindarti, 2008). Perusahaan yang memperoleh kerugian atau tingkat profitabilitas rendah nantinya akan membawa dampak buruk dari reaksi pasar dan akan menyebabkan turunnya penilaian kinerja suatu perusahaan (Srimindarti, 2008). Yuliani (2007) menyatakan bahwa Return On Asset (ROA) 
dipilih sebagai proksi atas kinerja keuangan perusahaan dikarenakan ROA dianggap sebagai indikator dari profitabilitas perusahaan dalam menggunakan asetnya untuk menghasilkan laba bersih. Ukuran kinerja keuangan yang dipakai adalah profitabilitas yang diartikan sebagai kemampuan perusahaan dalam menghasilkan laba. Profitabilitas perusahaan merupakan salah satu dasar penilaian kondisi suatu perusahaan, untuk itu dibutuhkan suatu alat analisis untuk bisa menilainyaAnwar (2011). Alat analisis yang dimaksud adalah rasio-rasio keuangan, seperti rasio profitabilitas yang digunakan untuk mengukur efektifitas manajemen berdasarkan hasil pengembalian yang diperoleh dari penjualan dan investasi (Brigham, 1993).

Hasil penelitian Anwar (2011) menyimpulkan bahwa Pengetahuan Manajer, Komitmen Organisasional dan Keberhasilan Penerapan SIA secara simultan berdampak positif dan signifikan terhadap Kinerja Keuangan Perusahaan (dimensi ROA, ROE, dan Profit Margin). Hasil penelitian Primasari (2011) menyimpulkan bahwa penggunaan informasi akuntansi berdampak positif terhadap bawahan dan informasi akuntansi sebagai penilaian prestasi seseorang. Hariadi (Syam, 2000) menemukan bahwa interaksi antara penggunaan informasi akuntansi sebagai alat penilai dan ketidakpastian tugas serta pengaruhnya terhadap tingkat ketegangan bawahan tidak signifikan.

Syam (2000) dalam penelitiannya menyimpulkan informasi akuntansi dan ketidakpastian tugas tidak berpengaruh signifikan terhadap prestasi dan kinerja manajer. Wahyuni (1994) dalam penelitiannya, menyatakan informasi akuntansi tidak berpengaruh positif dan signifikan pada kinerja manajerial dengan menempatkan 
ISSN: 2302-8556

E-Jurnal Akuntansi Universitas Udayana

Vol.25.3.Desember (2018): 1634 - 1661

ketidakpastian lingkungan sebagai variabel moderasi. Efendi (2001) dalam penelitiannya, menyimpulkan interaksi informasi akuntansi dan ketidakpastian tugas yang rendah berpengaruh positif secara signifikan terhadap kinerja manajer.

Dari pemaparan diatas, penelitian ini merupakan replikasi dari penelitian Efendi (2001). Penelitian ini berbeda dengan penelitian Efendi (2001), dimana adanya perbedaan variabel terikat yaitu profitabilitas, serta tempat penelitian yang berbeda. Oleh karena itu penelitian ini memiliki tujuan memperoleh bukti empiris mengenai kualitas SIA dan profitabilitas dengan ketidakpastian tugas sebagai variabel pemoderasi pada Lembaga Perkreditan Desa di Kota Denpasar.

Dari uraian latar belakang di atas, rumusan masalah pada penelitian ini yaitu: 1) Bagaimana pengaruh kualitas SIA pada profitabilitas?; 2) Bagaimana peran ketidakpastian tugas dalam memoderasi hubungan antara kualitas SIA pada profitabilitas?. Tujuan dalam penelitian ini adalah untuk memberi bukti empiris pengaruh kualitas sistem informasi akuntansi serta untuk memberi bukti empiris pengaruh peran ketidakpastian tugas dalam memoderasi hubungan antara kualitas sistem informasi akuntansi pada profitabilitas.

Dari tujuan penelitian, peneliti berharap berdasarkan hasil penelitian ini dapat memberikan kegunaans ecara teoritis maupun praktis. Kegunaan teoritis dalam penelitian dilakukan, diharapkan dapat memberikan pengetahuan dan wawasan bagi mahasiswa, serta dapat dijadikan referensi untuk penelitian dalam bidang sistem informasi akuntansi di masa yang akan datang. Sedangkan kegunaan praktis penelitian ini diharapkan dapat memberikan tambahan informasi sebagai bahan 
pertimbangan bagi Lembaga Perkreditan Desa (LPD) di dalam meningkatkan kualitas sistem informasi akuntansi.

Kajian pustaka dalam penelitian ini Teori Kontijensi. Teori Kontijensi merupakan teori yang berlandaskan pada suatu pemikiran bahwa pengelolaan organisasi dapat berjalan dengan baik dan lancar apabila pemimpin organisasi mampu memperhatikan dan memecahkan situasi tertentu yang sedang dihadapi dan setiap situasi harus dianalisis sendiri. Penerapan teori kontijensi bermanfaat untuk mengetahui pengaruh tingkat keandalan sistem akuntansi manajemen pada setiap kondisi (Otley, 1980). faktor kontijensi yang digunakan dalam penelitian ini adalah ketidakpastian tugas. Ketidakpastian tugas dalam kaitannya dengan LPD adalah rangkap jabatan yang kaitannya dengan fungsi, tugas, serta kepentingan yang berdampak negatif pada kualitas keputusan.

Secara sistematis, kerangka konseptual dalam penelitian ini dapat dilihat pada Gambar 1 sebagai berikut.

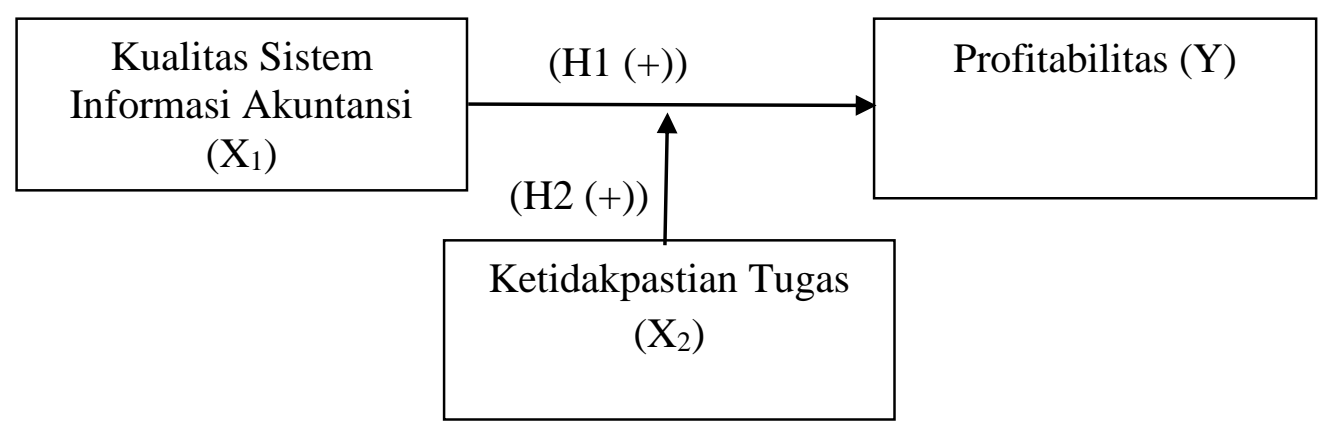

Gambar 1. Kerangka Konseptual 
ISSN: 2302-8556

E-Jurnal Akuntansi Universitas Udayana

Vol.25.3.Desember (2018): 1634 - 1661

Sistem informasi akuntansi dirancang untuk mengolah data menjadi informasi dimana informasi yang dihasilkan bersumber dari catatan catatan dan laporan akuntansi, sehingga dengan demikian segala sesuatu yang berdampak buruk terhadap profitabilitas dapat diketahui. Penerapan SIA dapat mempermudah pekerjaan, karena kinerja sistem aplikasi dapat meningkatkan produktifitas pekerjaan, sehingga mampu dalam peningkatan laba (Grande ,2011). Fakhmi (2008) dalam peneilitiannya, bahwa informasi akuntansi berpengaruh terhadap profitabilitas perusahaan. Anwar (2011) menyatakan keberhasilan penerapan SIA berdampak positif dan signifikan terhadap kinerja kinerja profitabilitas perusahaan. Berdasarkan uraian diatas, maka dapat dirumuskan hipotesis sebagai berikut:

$\mathrm{H}_{1}$ : Kualitas sistem informasi akuntansi berpengaruh pada profitabilitas.

Ketidakpastian tugas kaitannya erat dengan SIA yang dimana organisasi sebagai sistem sosial yang harus menghadapi ketidakpastian tugas teruntuk yang berkaitan dengan tugas, untuk itu untuk itu pengembangan teknologi informasi harus dimanfaatkan dan memiliki kesusaian yang baik dengan tugas yang didukungnya (Goodhue dan thompson, 1995). Interaksi antara pengguna informasi akuntansi sebagai alat penilai (relianceon accounting performance) dan ketidakpastian tugas (task uncertainty) menunjukkan signifikansinya terhadap tingkat ketegangan bawahan (Hariadi, 1990). Primasari (2011) dalam penelitiannya menunjukkan bahwa informasi akuntansi dapat digunakan oleh manajemen untuk proses perencanaan, koordinasi, dan penilaian evaluasi yang nantinya dijadikan pedoman dimasa mendatang. Hasil penelitian ini juga mempertegas terdapat pengaruh simultan yang signifikan antara 
ketidakpastian lingkungan, strategi bisnis, dan informasi akuntansi terhadap kinerja manajerial. Mengukur kinerja perusahaan dapat dilakukan dengan mengukur kemampulabaan (profitabilitas).

Profitabilitas merupakan hasil akhir dari berbagai kebijakan dan keputusan manajemen. Rasio profitabilitas akan memberi jawaban akhir tentang efektivitas manajemen perusahaan, rasio ini memberikan gambaran tentang efektivitas pengelolaan perusahaan (Fakhmi, 2008). Sedangkan dalam penelitian Jaryanto (2008) berbeda dengan penelitian-penelitian sebelumnya bahwa tidak terdapat pengaruh langsung yang signifikan antara ketidakpastian tugas terhadap kinerja manajerial. Berdasarkan uraian diatas, maka dapat dirumuskan hipotesis sebagai berikut:

$\mathrm{H}_{2}$ : Ketidakpastian tugas memperkuat kualitas sistem informasi akuntansi dalam mempengaruhi profitabilitas

\section{METODE PENELITIAN}

Penelitian ini menggunakan pendekatan kuantitatif yang berbentuk asosiatif. Penelitian ini menjelaskan tentang bagaimana pengaruh kualitas SIA pada profitabilitas dengan ketidakpastian tugasebagai variabel pemoderasi.Lokasi penelitian dilakukan di LPD Kota Denpasar. Lokasi ini dipilih karena LPD Kota Denpasar sudah mulai menerapkan SIA berbasis online serta aset yang dimiliki LPD Kota Denpasar terus meningkat setiap tahunnya. Objek penelitian yang menjadi kajian dalam penelitian ini adalah kualitas sistem informasi, dengan ketidakpastian tugas terhadap profitabilitas di kantor Lembaga Perkreditan Desa (LPD). 
ISSN: 2302-8556

E-Jurnal Akuntansi Universitas Udayana

Vol.25.3.Desember (2018): 1634 - 1661

Variabel merupakan atribut atau nilai atau sifat dari, obyek kegiatan yang mempunyai variasi tertentu yang ditetapkan oleh peneliti untuk dapat dipelajari dan kemudian dapat ditarik kesimpulannya (Sugiyono, 2016:39). Variabel terikat dalam penelitian ini adalah profitabilitas LPD. Profitabilitas merupakan kemampuan perusahaan untuk menghasilkan laba dan mencapai tujuan sebagai akibat menggunakan atau mengimplementasikan sistem informasi akuntansi.Pada penelitian ini, rasio profitabilitas dinyatakan dengan Return on Assets (ROA). ROA diperoleh dengan cara membandingkan laba terhadap total asset (Martono, 2004). Secara matematis ROA dapat dirumuskan sebagai berikut:

$$
\mathrm{ROA}=\frac{\text { Laba }}{\text { Total Asset }} \times 100 \%
$$

Variabel bebasyang digunakan dalam penelitian ini adalahsistem informasi akuntansi. Variabel ini diukur dari segi kualitas sistem informasi yang digunakan oleh LPD. Kualitas sistem informasi yang dimaksud dalam penelitian ini adalah kualitas software akuntansi yang digunakan.Terdapat 10 pernyataan dengan 5 skala Likert yang digunakan untuk mengukur variabel ini yang diadopsidari kuesioner yang digunakan oleh Arum (2011).

Variabel moderasi merupakan variabel yang memberikan pengaruh baik memperkuat atau memperlemah hubungan diantara variabel independen dan dependen. Variabel moderasi dalam penelitian ini adalah ketidakpastian tugas. Ketidakpastian tugas yang dimaksud dalam penelitian ini adalah masih adanya rangkap jabatan di LPD. Indikator yang digunakan untuk mengukur variabel ini 
diadopsi dari kuesioner yang digunakan oleh Efendi (2001), yaitu : prosedur kerja, pembagian kerja, metode kerja, dan kompleksitas kerja.

Populasi dalam penelitian ini adalah seluruh LPD yang terdapat di Kota Denpasar. Tercatat 35 LPD yang tersebar di 4 (empat) kecamatan. Untuk Kecamatan Denpasar Barat terdapat 2 LPD, Denpasar Utara terdapat 10 LPD, Denpasar Timur terdapat 12 LPD, dan Denpasar Selatan terdapat 11 LPD.Teknik sampling jenuh merupakan teknik penentuan sampel yang digunakan dalam penelitian ini. Teknik ini merupakan teknik pengambilan sampel dengan semua poulasi digunakan sebagai sampel, dikenal dengan istilah sensus, sehingga sampel dalam penelitian ini berjumlah 35 LPD yang terdapat di Kota Denpasar.

Pengumpulan data pada penelitian ini adalah data primer yang diperoleh langsung dari LPD yang dapat diperoleh dengan metode survei yang dilakukan dengan pengumpulan data melalui pengisian kuesioner yang dapat dilakukan dengan mengunjungi responden penelitian ke lokasi penelitian. Kuesioner yang disebarkan berupa daftar pernyataan kepada responden mengenai sistem informasi akuntansi, ketidakpastian tugas, dan profitabilitas. Hasil jawaban tersebut kemudian diukur dengan menggunakan skala likert, yaitu pilihan jawaban responden diberi nilai dengan skala 5 poin. Teknik analisis data pada penelitian ini adalah Regresi Linier sederhana dan teknik analisis regresi moderasi (MRA) dihitung dengan SPSS. Pengujian dilanjutkanapabila model dalam penelitian telah memenuhi syarat yaitu data harustidak mengandung heteroskedastisitas serta autokorelasi dan berdistribusi normal (uji asumsi klasik). Pengujian selanjutnya yaitu, uji kelayakan model (uji F) 
ISSN: 2302-8556

uji koefisien determinasi $\left(\mathrm{R}^{2}\right)$, setelah itu ujiregresi linier sederhana, uji MRA,uji hipotesis (Uji t), dan statistik deskriptif. Model regresi penelitian ini dapat ditunjukkan dengan persamaan berikut.

Model regresi linier sederhana :

$\mathrm{Y}=\mathrm{a}+\beta 1 \mathrm{X} 1+\mathrm{e}$

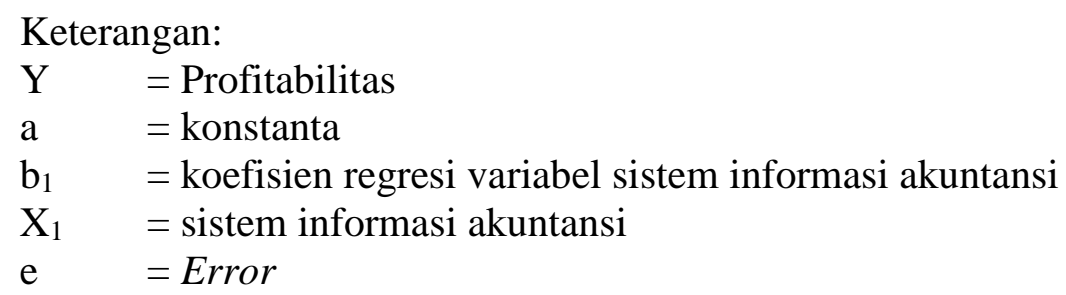

Model regresi moderasi /MRA

$\mathrm{Y}=\alpha+\beta 1 \mathrm{X} 1+\beta 2 \mathrm{X} 2+\beta 3 \mathrm{X} 1 \mathrm{X} 2+\mathrm{e}$

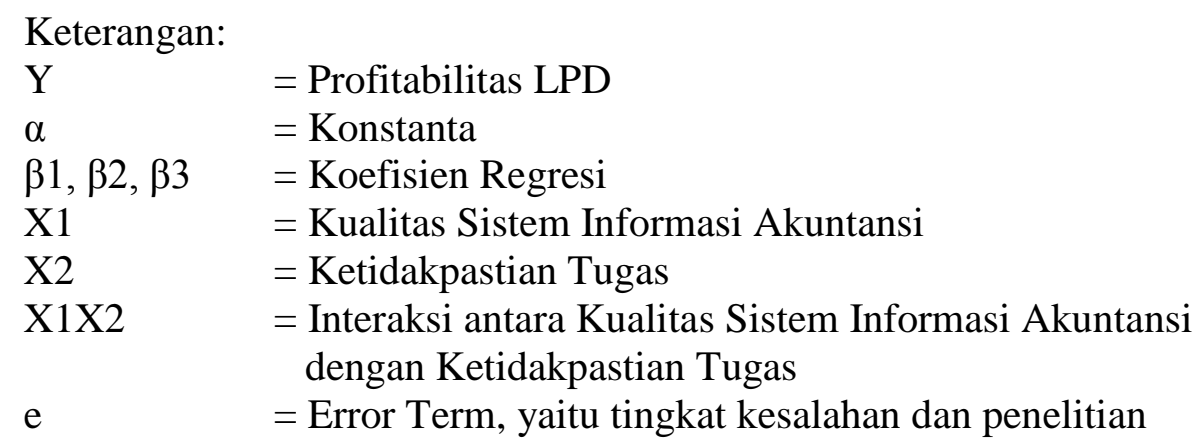

\section{HASIL DAN PEMBAHASAN}

Data penelitian diperoleh dari hasil kuesioner yang telah disebarkan kepada 35 LPD di Kota Denpasar yaitu Denpasar Barat sebanyak 2 LPD, Denpasar Utara sebanyak 10 LPD, Denpasar Timur sebanyak 12 LPD, dan Denpasar Selatan sebanyak 11 LPD. Ringkasan mengenai karakteristik responden dapat dilihat pada Tabel 4 berikut ini. 
Distribusi kuesioner beserta tingkat pengembalian kuesioner yang dpaat diolah disajikan dalam Tabel 1 sebagai berikut:

Tabel 1.

Rincian Pengiriman dan Pengembalian Kuesioner

\begin{tabular}{|c|c|}
\hline Keterangan & Jumlah \\
\hline Kuesioner yang disebar & 35 \\
\hline Kuesioner yang tidak kembali & - \\
\hline Kuesioner yang dikembalikan & 35 \\
\hline Kuesioner yang digunakan & 35 \\
\hline Tingkat Pengembalian (Respons rate) & \\
\hline Kuesioner yang dikembalikan x $100 \%$ & $100 \%$ \\
\hline Kuesioner yang dikirim & \\
\hline $\begin{array}{l}\text { Tingkat Pengembalian yang digunakan (useable response rate) } \\
\text { Kuesioner yang diolah x } 100 \% \\
\text { Kuesioner yang dikirm }\end{array}$ & $100 \%$ \\
\hline
\end{tabular}

Berdasarkan tabel 1 dapat dijelaskan bahwa kuesioner yang disebar sebanyak 35 buah eksemplar dengan tingkat pengembalian 100\% sehingga total kuesioner yang digunakan sebanyak 35 buah.

Statistik deskriptif bertujuan untuk memberikan informasi mengenai karakteristik variabel - variabel penelitian yaitu jumlah amatan nilai minimum, nilai maksimum, nilai mean, dan standar deviasi (Sugiyono, 2014:207). Hasil dari statistik deskriptif penelitian dapat dilihat pada Tabel 2 berikut:

Tabel 2.

Hasil Statistik Deskriptif Variabel Penelitian

\begin{tabular}{lrrrrr}
\hline & N & Minimum & Maximum & Mean & Std. Deviation \\
\hline Kualitas SIA & 35 & 13 & 50 & 36.03 & 9.745 \\
Ketidakpastian Tugas & 35 & 4 & 20 & 13.71 & 4.356 \\
Profitabilitas & 35 & 1.20 & 8.36 & 3.79 & 1.351 \\
Valid N (listwise) & 35 & & & & \\
\hline
\end{tabular}

Sumber :Data diolah, 2018

Tabel 2 menunjukan variabel kualitas SIA memiliki nilai minimum 13dan nilai maksimum 50. Nilai rata-rata untuk variabel partisipasi anggaran sebesar 36,03 
ISSN: 2302-8556

dengan penyimpangan sebesar 9,745.Hal ini berarti berdasarkan hasil statistik deskriptif, terjadi perbedaan nilai kualitas SIA yang diteliti terhadap nilai rata-ratanya sebesar 9,745 .

Variabel ketidakpastian tugas memiliki nilai minimum 4 dan nilai maksimum 20. Nilai rata-rata untuk variabel ketidakpastian tugas sebesar 13,71 dengan penyimpangan sebesar 4,356.

Variabel profitabilitas memiliki nilai maksimum 8,36 dan nilai minimum yaitu 1,20. Nilai rata-rata untuk variabel profitabilitas sebesar 3,79 dengan penyimpangan sebesar 1,351 .

Tujuan dilakukannya uji normalitas yaitu untuk menguji apakah dalam residual dari model regresi yang dibuat telah berdistribusi normal. Uji KomogorovSminarnov dilakukan untuk menguji uji normalitas. Pada analisis regresi moderasi, Nilai Asymp. Sig. (2-tailed) yang disajikan pada Tabel 3 yaitu sebesar 0,683, yang dimana lebih besar dari 0,05 maka dapat disimpulkan bahwa seluruh data berdistribusi normal.

Tabel 3.

Hasil Uji Normalitas

\begin{tabular}{|c|c|c|}
\hline & & $\begin{array}{c}\text { Unstandardized } \\
\text { Residual } \\
\end{array}$ \\
\hline$\overline{\mathrm{N}}$ & & 35 \\
\hline \multirow[t]{2}{*}{ Normal Parameters ${ }^{\mathrm{a}, \mathrm{b}}$} & Mean & .0000000 \\
\hline & Std. Deviation & .76012548 \\
\hline \multirow[t]{3}{*}{ Most Extreme Differences } & Absolute & .121 \\
\hline & Positive & .121 \\
\hline & Negative & -.058 \\
\hline Kolmogorov-Smirnov Z & & .717 \\
\hline Asymp. Sig. (2-tailed) & & .683 \\
\hline
\end{tabular}


Uji autokorelasi dilakukan untuk melacak adanya korelasi data dari tahun $\mathrm{t}$ dengan tahun t-1 (sebelumnya). Pengujian autokorelasi dilakukan melalui DurbinWatson test, dimana model regresi dikatakan terbebas dari autokorelasi apabila sesuai dengan kriteria $d u<D W<4-d u$. Hasil uji autokorelasi dapat dilihat pada Tabel 4 sebagai berikut.

Tabel 4.

Hasil Uji Autokorelasi

\begin{tabular}{lcccc}
\hline \multicolumn{1}{c}{ Persamaan } & Dl & Du & DW & Simpulan \\
\hline $\mathrm{Y}=\mathrm{a}+\beta_{1} \mathrm{X}_{1}+\beta_{2} \mathrm{X}_{2}+\beta_{3} \mathrm{X}_{1} \mathrm{X}_{2}+\mathrm{e}$ & 1,2833 & 1,6528 & 1,980 & Bebas autokorelasi \\
\hline Sumber: Data diolah, 2018. & & & &
\end{tabular}

Berdasarkan hasil perhitungan tabel diatas, persamaan regresi moderasi memiliki nilai Durbin-Watson sebesar 1,980. Untuk tingkat signifikansi 5\%, nilai $\mathrm{dl}=$ 1,2833 dan $\mathrm{du}=1,6528$. Dengan demikian hasil uji autokorelasi dengan kriteria $\mathrm{du}<\mathrm{DW}<4$-du adalah $1,6528<1,980<2,347$, maka dapat disimpulkan bahwa model regresi yang dibuat tidak mengandung gejala autokorelasi.

Tujuan dilakukannya uji heteroskedatisitas yaitu untuk menguji apakah dalam model regresi terjadi ketidaksamaan variance dari residual untuk semua pengamatan. Uji Glejser digunakan untuk menguji uji heterokedastisitas di dalam penelitian ini. Apabila tingkat signifikansi lebih besar dari $\alpha=0,05$ maka model regresi yang dianalisis tidak adanya gejala heteroskedastisitas. Pada Tabel5 disajikan hasil uji heteroskedastisitas, sebagai berikut. 
ISSN: 2302-8556

E-Jurnal Akuntansi Universitas Udayana

Vol.25.3.Desember (2018): 1634 - 1661

Tabel 5.

Hasil Uji Heteroskedastisitas

\begin{tabular}{cccc}
\hline Persamaan & Variabel & t & Sig \\
\hline & Kualitas SIA $\left(\mathrm{X}_{1}\right)$ & 1,718 & 0,096 \\
$\mathrm{Y}=\mathrm{a}+\beta_{1} \mathrm{X}_{1}+\beta_{2} \mathrm{X}_{2}+\beta_{3} \mathrm{X}_{1} \mathrm{X}_{2}+\mathrm{e}$ & Ketidakpastian tugas $\left(\mathrm{X}_{2}\right)$ & $-1,063$ & 0,296 \\
& $\begin{array}{c}\text { Interaksi antara kualitas SIA } \\
\text { dengan ketidakpastian tugas } \\
\left(\mathrm{X}_{1} * \mathrm{X}_{2}\right)\end{array}$ & 0,080 & 0,937 \\
& & & \\
\hline
\end{tabular}

Sumber : Data diolah, 2018

Dari hasil pengujian pada Tabel 5, tingkat signifikansi seluruh variabel berada diatas 0,05 hal ini menunjukkan model regresi moderasi dalam penelitian ini bebas dari heteroskedastisitas.

Uji analisis regresi Sederhana digunakan untuk mengetahui apakah variabel kualitas sistem informasi akuntansi berpengaruh terhadap profitabilitas pada LPD seKota Denpasar, maka digunakan analisis regresi linier sederhana. Hasil uji analisis regresi linier sederhana dalam penelitian ini dapat dilihat pada Tabel 6 berikut.

\section{Tabel 6.}

Hasil Regresi Sederhana

\begin{tabular}{|c|c|c|c|c|c|}
\hline \multirow[t]{2}{*}{ Model } & \multicolumn{2}{|c|}{$\begin{array}{l}\text { Unstandardized } \\
\text { Coefficients }\end{array}$} & $\begin{array}{c}\text { Standardized } \\
\text { Coefficients }\end{array}$ & \multirow[b]{2}{*}{$\mathbf{t}$} & \multirow[b]{2}{*}{ Sig. } \\
\hline & B & Std. Error & Beta & & \\
\hline (Constant) & .893 & .733 & & 1.219 & .231 \\
\hline Kualitas SIA & .081 & .020 & .581 & 4.097 & .000 \\
\hline R Square & & & & & 0,337 \\
\hline Adjusted R Square & & & & & 0,317 \\
\hline F Hitung & & & & & 16,788 \\
\hline Signifikansi F & & & & & 0,000 \\
\hline
\end{tabular}

Sumber : Data diolah, 2018

Berdasarkan tabel diatas dapat disusun persamaan regresi adalah sebagai berikut.

$$
\mathrm{Y}=0,893+0,081 \mathrm{X}_{1}+\varepsilon
$$

Nilai koefisien regresi variabel Kualitas sistem informasi akuntansi bernilai positif dengan nilai signifikansi uji t kurang dari 0,05. Hal ini menunjukkan bahwa variabel Kualitas sistem informasi akuntansi memiliki pengaruh positif yang 
signifikan terhadap variabel terikat. Tabel 6 menunjukkan nilai $\mathrm{R}$ Square pada analisis regresi linier sederhana sebesar 0,337 . Hal ini berarti bahwa sebesar 33,7 persen profitabilitas yang diperoleh LPD se-Kota Denpasar dipengaruhi oleh kualitas sistem informasi akuntansi yang tersedia.

Uji regresi moderasi/MRA bertujuan untuk mengetahui apakah variabel moderasi yaitu ketidakpastian tugas mampu mempengaruhi hubungan antara variabel bebas dan variabel terikat, dimana dalam persamaan regresinya mengandung unsur interaksi. Hasil analisis uji moderasi menggunakan program SPSS dapat dilihat pada tabel 7 berikut.

Tabel 7. Hasil Uji Interaksi (Moderated Regression Analysis)

\begin{tabular}{|c|c|c|c|c|c|}
\hline \multirow[t]{2}{*}{ Model } & \multicolumn{2}{|c|}{$\begin{array}{l}\text { Unstandardized } \\
\text { Coefficients }\end{array}$} & \multirow{2}{*}{$\begin{array}{c}\begin{array}{c}\text { Standardized } \\
\text { Coefficients }\end{array} \\
\text { Beta } \\
\end{array}$} & \multirow[t]{2}{*}{$\mathbf{t}$} & \multirow[t]{2}{*}{ Sig. } \\
\hline & B & Std. Error & & & \\
\hline 1 (Constant) & .492 & .559 & & .881 & .385 \\
\hline Kualitas SIA & .052 & .016 & .377 & 3.189 & .003 \\
\hline Ketidakpastian tugas & -.071 & .049 & -.229 & -1.448 & .158 \\
\hline $\begin{array}{l}\text { Interaksi Antara Kualitas SIA dengan } \\
\text { Ketidakpastian tugas }\end{array}$ & .181 & .035 & .771 & 5.175 & .000 \\
\hline R Square & & & & & 0,684 \\
\hline Adjusted R Square & & & & & 0,653 \\
\hline F Hitung & & & & & 22,322 \\
\hline Signifikansi F & & & & & 0,000 \\
\hline
\end{tabular}

Sumber : Data diolah, 2018

Berdasarkan hasil analisis regresi moderasi seperti yang disajikan pada Tabel

7, maka persamaan strukturalnya adalah sebagai berikut :

$$
\mathrm{Y}=0,492+0,052 \mathrm{X}_{1}-0,071 \mathrm{X}_{2}+0,181 \mathrm{X}_{1} \mathrm{X}_{2}+\mathrm{e}
$$

Nilai koefisien regresi variabel Kualitas sistem informasi akuntansi bernilai positif dengan nilai signifikansi uji t kurang dari 0,05. Hal ini menunjukkan bahwa variabel Kualitas sistem informasi akuntansi memiliki pengaruh positif yang 
ISSN: 2302-8556

E-Jurnal Akuntansi Universitas Udayana

Vol.25.3.Desember (2018): 1634 - 1661

signifikan terhadap variabel terikat. Nilai koefisien regresi variabel ketidakpastian tugas bernilai negatif dengan nilai signifikansi uji t lebih dari 0,05. Hal ini menunjukkan bahwa variabel ketidakpastian tugas tidak berpengaruh secara signifikan terhadap variabel terikat. Sedangkan nilai koefisien regresi variabel Interaksi Antara kualitas SIA dengan Ketidakpastian tugasbernilai positif dengan nilai signifikansi uji t lebih dari 0,05. Hal ini menunjukkan bahwa variabel Interaksi Antara kualitas SIA dengan Ketidakpastian tugas berpengaruh secara positif signifikan terhadap variabel terikat.

Nilai Adjusted R Square model (Uji koefisien determinasi) pada tabel 7 uji analisis regresi moderasi sebesar 0,653 artinya 65,3 persen senjangan anggaran dipengaruhi oleh partisipasi anggaran, informasi asimetri, komitmen organisasi, dan ketidakpastian lingkungan, sedangkan 46,7 persen dijelaskan oleh variabel lain diluar model.

Hasil uji F (Ftest) pada tabel 7 menunjukkan bahwa nilai signifikansi $\mathrm{P}$ value 0,000 yang lebih kecil dari $\alpha=0,05$, ini berarti model yang digunakan pada penelitian ini adalah layak. Hasil ini memberikan makna bahwa seluruh variabel independen yaitu Kualitas SIA, ketidakpastian tugas, dan variabel interaksi antara kualitas SIA dengan Ketidakpastian tugas mampu memprediksi atau menjelaskan fenomena Profitabilitas pada seluruh sampel LPD yang ada di Kota Denpasar.

Berdasarkan hasil uji analisis regresi moderasi, menunjukkan pengaruh kualitas sistem informasi akuntansi diperoleh nilai signifikansi sebesar $0,003<0.05$ (significant) dengan nilai koefisien regresi sebesar 0,052, yang berarti bahwa kualitas 
SIA berdampak positif dan signifikan pada profitabilitas di LPD kota Denpasar. Hal tersebut menunjukkan bahwa semakin baik kualitas SIA yang dimiliki oleh LPD, maka akan mempengaruhi peningkatan profitabilitas pada LPD tersebut. Begitu pula sebaliknya, semakin buruk kualitas sistem informasi akuntansi yang dimiliki oleh LPD, maka akan berdampak pada menurunnya profitabilitas LPD tersebut.Sistem informasi akuntansi dirancang untuk mengolah data menjadi informasi dimana informasi yang dihasilkan bersumber dari catatan catatan dan laporan akuntansi, sehingga dengan demikian segala sesuatu yang berdampak buruk terhadap profitabilitas dapat diketahui.

Hasil penelitian ini didukung oleh temuan penelitian Fakhmi (2008) yang memperoleh hasil bahwa SIA berpengaruh terhadap profitabilitas perusahaan. Hasil penelitian ini juga sejalan dengan temuan penelitian Anwar (2011) yang menyatakan bahwa keberhasilan penerapan sistem informasi akuntansi berdampak positif dan signifikan terhadap kinerja keuangan perusahaan (kinerja profitabilitas).

Berdasarkan hasil uji analisis regresi moderasi, variabel kualitas SIA dengan ketidakpastian tugas sebagai variabel moderasi menunjukan tingkat signifikansi 0,000 $<$ 0,05 dengan nilai koefisien regresi sebesar 0,181 , hal ini berarti bahwa ketidakpastian tugas secara statistik mampu memoderasi pengaruh Kualitas SIA pada profitabilitas. Hal ini menunjukkan bahwa terdapat interaksi ketidakpastian tugas dan kualitas sistem informasi akuntansi dalam mempengaruhi profitabilitas. Apabila karyawan LPD memperoleh ketidakpastian tugas yang tinggi maka akan dapat mempengaruhi hasil kerja karyawan tersebut yang akan berdampak pada 
ISSN: 2302-8556

E-Jurnal Akuntansi Universitas Udayana

Vol.25.3.Desember (2018): 1634 - 1661

profitabilitas. Ketidakpastian tugas yang tinggi yang disebabkan karena adanya kesalahan manajemen yang kurang tepat dari pihak manajemen LPD tentu akan mempengaruhi kinerja karyawan dalam menggunakan sistem informasi akuntansi, sehingga dapat mempengaruhi profitabilitas yang diperoleh LPD.

Hasil penelitian ini sesuai penelitian yang dilakukan Primasari (2011) yang menunjukkan bahwa informasi akuntansi dapat digunakan oleh manajemen untuk proses perencanaan, koordinasi, dan penilaian evaluasi yang nantinya dijadikan pedoman dimasa mendatang. Namun dengan adanya ketidakpastian tugas, maka kinerja karyawan menjadi tidak maksimal sehingga berpengaruh pada profitabilitas yang diperoleh. Hasil penelitian ini juga sesuai dengan temuan penelitian Hariadi (1990), Hirst (1981), Hariadi (1990) Saleke (1994), Poniman (2005), dan Fakhmi (2008) yang menyatakan bahwa terdapat pengaruh yang signifikan pada interaksi antara pengguna informasi akuntansi sebagai alat penilai (relianceon accounting performance) dan ketidakpastian tugas (task uncertainty)

Berdasarkan pembahasan yang telah diuraikan terdapat beberapa implikasi penelitian yang dapat dimanfaatkan adalah Penelitian ini menghasilkan bukti empiris bahwa kualitas SIA berpengaruh positif dan signifikan pada profitabilitas LPD di Kota Denpasar. Hal ini dapat dikaitkan dengan teori kontijensi yang bermanfaat untuk mengetahui pengaruh tingkat keandalan sistem akuntansi akuntansi pada setiap kondisi. Dengan penerapan sistem informasi akuntansi yang berkualitas dapat meningkatkan kinerja organisasi. Indikator kinerja LPD dapat dilihat dari 
profitabilitas, kecepatan dalam melakukan pelayanan kepada masyarakat, dan kualitas sistem informasi akuntansi yang dihasilkan dengan tingkat akurasi yang tinggi dapat meningkatkan kepercayaan masyarakat.

Ketidakpastian tugas secara statistik juga telah mampu memoderasi pengaruh Kualitas SIA pada profitabilitas LPD di Kota Denpasar. Hal ini juga dapat dikaitkan dengan teori kontijensi dalam usaha memahami hubungan antara kualitas sistem informasi akuntansi dengan profitabilitas pada LPD. Apabila karyawan LPD memperoleh ketidakpastian tugas yang tinggi maka akan dapat mempengaruhi hasil kerja karyawan tersebut yang akan berdampak pada profitabilitas. Ketidakpastian tugas yang tinggi yang disebabkan karena adanya kesalahan manajemen yang kurang tepat dari pihak manajemen LPD tentu akan mempengaruhi kinerja karyawan dalam menggunakan sistem informasi akuntansi, sehingga dapat mempengaruhi profitabilitas yang diperoleh LPD.

\section{SIMPULAN}

Berdasarkan hasil penelitian yangtelah dijelaskan sebelumnya, simpulan yang diperoleh adalah penelitian ini kualitas sistem informasi akuntansi berpengaruh positif dan signifikan pada profitabilitas dan ketidakpastian tugas mampumemoderasi pengaruh Kualitas sistem informasi akuntansi pada profitabilitas, Hal ini menunjukkan bahwa terdapat interaksi ketidakpastian tugas dan kualitas sistem informasi akuntansi dalam mempengaruhi profitabilitas. Ketidakpastian tugas yang tinggi tersebut disebabkan karena adanya kesalahan manajemen yang kurang tepat 
ISSN: 2302-8556

E-Jurnal Akuntansi Universitas Udayana

Vol.25.3.Desember (2018): 1634 - 1661

dari pihak manajemen LPD tentu akan mempengaruhi kinerja karyawan dalam menggunakan sistem informasi akuntansi, sehingga dapat mempengaruhi profitabilitas yang diperoleh LPD.

Saran yang dapat peneliti usulkan berdasarkan hasil penelitian dan simpulan yang telah diuraikan di atas adalahuntuk Lembaga LPD diharapkan selalu memberikan pendidikan dan pelatihan secara berkala kepada karyawan LPD, agar karyawan mampu beradaptasi terhadap hal-hal baru khususnya mengenai sistem informasi akuntansi sehingga dapat meningkatkan kinerja karyawan tersebut. Pihak manajemen LPD juga diharapkan dapat meminimalisir adanya ketidakpastian tugas yang dilakukan karyawan, sehingga karyawan dapat bekerja lebih efektif dan efisien guna meningkatkan kinerja LPD itu sendiri.

Untuk peneliti selanjutnya diharapkan dapat memperluas ruang lingkup wilayah penelitian tidak hanya pada lingkup daerah tertentu saja, melainkan mencakup lingkup daerah yang lebih luas serta pada instansi yang berbeda, sehingga dapat mewakili populasi dengan jumlah yang lebih besar.

\section{REFERENSI}

Abdel, Lu'ay Mohammad, Rahman Wedyan. 2012. Affectof Applying Accounting Information System on the Profitability of Commercial Banks in Jordan (A Field Study from Management's Viewpoint). Journal of Management Research. ISSN 1941 - 899X. Jordan: Al Balqa Applied University.

Aplonia, Elfreda dan Imam Gozali. 2003. Pengaruh Partisipasi terhadap Kepuasan Pemakai dalam Pengembangan sistem Informasi dengan Lima Variabel Moderating. SNA VI. Surabaya. 
Bodnar, George \& William Hopwood. 2006. Accounting Information System. 8th Edition. New Jersey: Prentice Hall Inc.

Brownell, P. 1981. Participation in Budgetting Process, Locus of Control and organizational Effectiveness. The Accounting Review.

Chin, W. dan Todd, P. 1995. On The Usefullness, Ease of use of Structural Equation Modeling in MIS Research: A note of Caution. Journal of Management Information System Quarterly.

Daft, R., and R. Lengel. 1986. "Organizational Information Requirements, Media Richness and Structural Design”. Management Science.

Davis, Fred D., Bagozzi, Richard P., dan Warshaw, Paul R. 1989. User Acceptance Of Computer Technology: A Comparison Two Theoretical Models, Management Science.

DeLone \& McLean. 1992. Information System Success: The Quest for The Dependent Variable. Information System Research.

Efendi, David. 2001. "Pengaruh Informasi Akuntansi terhadap Kinerja Manajer dengan Ketidakpastian Tugas sebagai Variabel Moderating” (tesis) .Semarang: Magister Sains Akuntansi UNDIP.

Fakhmi, El. 2008. Peranan Pengendalian Intern dan Sistem Informasi Akuntansi dalam Pencapaian Profitabilitas (Studi Kasus pada PT. Reiyhan Pratama Putra).Avaiable from: journal.unsil.ac.id/jurnalunsil-986-.html (diakses tanggal 21/2/2013).

Galbraith.J. 1973. Designing Complex Organizations, Reading, Mass: AddisonWesley Publishing Company.

Goodhue, D.L., and Thompson, R.L. 1995. Task-Technology Fit and Individual Performance, MIS Querterly.

Grande, E., Estébanez, R., \& Colomina . The impact of Accounting Information Systems (AIS) on performance measures: empirical evidence in Spanish SMEs1. The International Journal of Digital Accounting Research.

1983. Reliance on Accounting Performance Measure, Task Uncertainty, and Dysfunctional Behaviour: Some Extension. Journal of Accounting Research.

Ishak, Muhammad. 1999. Akuntansi sebagai ilmu: Suatu Perubahan Paradigma. 
ISSN: 2302-8556

E-Jurnal Akuntansi Universitas Udayana

Vol.25.3.Desember (2018): 1634 - 1661

LJIMedia Akuntansi, No. 33/VI Maret-April 1999.

. 2007. Metodologi Penelitian Bisnis: Salah Kaprah dan PengalamanPengalaman. Cetakan Pertama. Yogyakarta: BPFE.

Miliken, F.J. 1987. Three Types of Perceived Uncertainty About The Environment: State, Effect and Response Uncertainty, Journal ofAcademy of Management Review.

Muhindo, Augustine, Maureen Kapute Mzuza, and Jian Zhou. 2014. Impact of Accounting Information Systems on Profitability of Small Scale Businesses: A Case of Kampala City in Uganda. International Journal of Academic Research in Management.

Norita. 2003. Pengaruh Kualitas Informasi Akuntansi dan Kualitas Manajer terhadap Pencapaian Laba pada Perusahaan Garmen di Kawasan Pulogadung dan Kawasan Berikat Nusantara Jakarta. Jurnal Simposium Nasional Akuntansi VII. Denpasar.

Otley, David T. 1978. Budget Use and Manajerial Performance. Journal of Accounting Research.

1980. The Contingency Theory of Management Accounting: Achievementand Prognosis. Accounting, Organizationand Society.

Poniman. 2005. Pengaruh Informasi Akuntansi terhadap Kinerja Perusahaan dengan Ketidakpastian Lingkungan dan Strategi Bisnis sebagai Variabel Moderating. Jurnal Administrasi Bisnis. Semarang, Politeknik Negeri Semarang.

Primasari, Dona dan Isbandriyati Mutmainah. 2011. Pengaruh Informasi Akuntansi terhadap Kinerja Manajerial dengan Tiga Variabel Moderating (Studi Empiris pada BPR di Kabupaten Bogor). Jurnal Reviw Akuntansi dan Keuangan.

Riyanto L. S, Bambang. 2001. Alternative Approach to Examining a Contigency Model in Accounting Research: A Comparation. Jurnal Riset Akuntansi, Manajemen dan Ekonomi.

Solikin, Ikin dan Memen Kustiawan. 2010. Meningkatkan Kualitas Informasi Akuntansi melalui Pemberdayaan Aparatur Pemerintah dalam Mewujudkan Good Governance. Jurnal Ilmu Administrasi.

Srimindarti Ceacilia. 2008. Ketepatan Waktu Pelaporan Keuangan. Fokus Ekonomi. 
Syam, Fazli. 2000. Informasi Akuntansi, Ketidakpastian Tugas dan Perilaku Manajer: Suatu Eksperimen Semu tesis .Yogyakarta: Program Pasca Sarjana Studi Akuntansi UGM .

Tjahjono, Heru Kurnianto dan Herland Alfa Stevany. 2002. Pengaruh Partisipasi dan Ketidakpastian Tugas dalam Pengembangan Sistem Informasi Manajemen pada Kinerja Sistem Informasi. Jurnal Ekonomi Manajemen. Universitas Muhammadiyah Yogyakarta.

Wahyuni, Endang Dwi. 1994. Pengaruh Informasi Akuntansi dan Ketidakpastian Lingkungan terhadap Prestasi Kerja Manajer pada Perusahaan Manufaktur di Jawa Timu tesis. Yogyakarta: Program Pasca Sarjana Studi Akuntansi UGM.

Woodward, J. 1965. Industrial Organization: Theory and Practice. Oxford: Oxford University Press.

Yuliani. 2007. Hubungan Efisiensi Operasional dengan Kinerja Profitabilitas pada Sektor Perbankan yang Go Publik di Bursa Efek Jakarta. Jurnal Manajemen \&Bisnis Sriwijaya.

Zigurs, Ilze and Buckland, Bonnie K. 1998. A Theory of Task/Technology Fit and Group Support System Effectiveness. MIS Quarterly. 